\title{
Seed storage protein variation in Arachis species
}

\author{
P.G. LANHAM, B.P. Forster, ${ }^{1}$ AND P. MCNiCOL \\ Scottish Crop Research Institute, Invergowrie, Dundee DD2 SDA, U.K. \\ J.P. Moss \\ International Crops Research Institute for the Semi-Arid Tropics, Patancheru, Andhra Pradesh" 502 3.24, India \\ AND \\ W. POWELL \\ Scottish Crop Research Institute, Invergowrie, Dundee DD2 5DA, U.K. \\ Corresponding Editor: G. Fedak \\ Received July 20, 1993 \\ Accepted-January 31, 1994
}

La.nham, P.G., Forster, B.P., McNicol, P., Moss, J.P., and Powell, W. 1994. Seed storage protein variation in Arachis species. Genome, 37: 487--496.

Seventy-two accessions, representing 22 species from sections Arachis, Erectoides, Extranervosae, and Triseminalae of the genus Arachis, were screened for seed storage protein polymorphism. Variation was detected between sections; between genome types, between species, and in some cases between different accessions of the same species or different seeds of the same accession. Arachis duranensis and one accession of A. cardenasii were found to have identical protein patterns. The greatest dissimilarity was found between species of the section Extranervosae and species of the section Triseminalae. Those of section Erectoides showed much similarity with some species of section Arachis. Protein polymorphism was shown to distinguish the two subspecies of A. hypogaea (fastigiata and hypogaea) in 27 of 28 cases. The seed protein profile of A. monticola was a combination of seed protein profiles from the two A. hypogaea subspecies. The relatedness between the various species was calculated and those that had the greatest similarity with $A$. hypogaea were $A$. spegazzinii and $A$. batizocoi.

Key words: Arachis, groundnut, storage proteins, variation.

Lanham, P.G., Forster, B.P., McNicol, P., Moss, J.P., et Powell, W. 1994. Seed storage protein variation in Arachis species. Genome, 37 : 487-496.

Soixante-douze accessions, représentant 22 espèces des sections Arachis, Erectoides, Extranervosae et Triseminalae du genre Arachis, ont fait l'objet d'une étude portant sur le polymorphisme des protéines de réserve des graines. De la variation a été détectée entre les sections, les types de génomes, les espèces et, dans certains cas, entre différentes accessions d'une même espèce ou différentes graines d'une même accession. L'Arachis et une accession d'A. cardenasii se sont avéré posséder des profils protéiques identiques. La plus grande dissimilarité a été trouvée entre les espèces de la section Extranervosae et celles de la section Triseminalae. Les espèces de la section Erectoides ont présenté beaucoup de similarité avec certaines espèces de la section Arachis. Le polymorphisme des protéines a permis de distinguer les deux sous-espèces d'A. hypogaea (fastigiata et hypogaea) dans 27 cas sur 28. Le profil des protéines des graines d'A. monticola s'est révélé être une combinaison des profils protéiques des graines des deux sous-espèces d'A. hypogaea. Le niveau des liens entre les diverses espèces a été calculé et les espèces dont le degré de similarité a été le plus élevé avec l'A. hypogaea ont été l'A. spegazzinii et l'A. batizocoi.

Mots clés: Arachis, arachide, protéines de réserve, variation.

[Traduit par la rédaction]

\section{Introduction}

The genus Arachis consists of seven sections (Gregory et al. 1980; Ressler 1980; Stalker and Moss 1987), one of which, section Arachis, includes the cultivated groundnut A. hypogaea L. and its wild progenitor A. monticola Krap. et Greg., both of which: are tetraploid $(2 n=4 x=40)$. The remainder of the section consists of wild diploid species. These wild accessions constitute a valuable source of novel germplasm for the introgression of pest and disease resistance genes into. A. hypogaea (Moss et al. 1988). The utility of species from other sections of the genus is limited by difficulties in producing fertile intersectional hybrids with A. hypogaea (Stalker and Moss 1987). Nine different genome types have been recognized in the genus: A, B, and D (section Arachis); E (section Erectoides); Ex (section Extranervosae); $\mathrm{T}$ (section Triseminalae); Am (section Ambinervosae); C (section Caulorhizae); and R (section Rhizomatosae; Smartt and Stalker 1982; Stalker 1985).

\footnotetext{
${ }^{1}$ Corresponding author.

The study of seed protein profiles is a useful method for species identification, clarifying taxonomic and evolutionary problems, and studying genetic diversity (Ladizinsky and Hymowitz 1979.) and has been successfully used with a wide range of plant species, for example, Ricinus communis (Sathaiah and Reddy 1985), Lolium sp., Festuca sp., Vulpia sp. (Bulinska-Radomska and Lester 1986, 1988), Citrullus sp. (Navot and Zamir 1987), Capsicum sp. (Panda et al. 1986), Zizania sp. (Duvall and Biesboer 1989), and Brachypodium sp: (Khan 1992). Klozova et al. (1983), Singh et al. (1991), and Bianchi-Hall et al. (1993) used seed protein profiles to examine relationships within the genus Arachis. Klozova: et al. (1983) screened 10 wild species, five species of the cultivated groundnut, and one "synthetic" hybrid for seed protein polymorphisms and found this approach most useful for distinguishing species within sections. Singh et al. (1991) determined the seed protein profiles of nine section Arachis wild species, eight cultivars of $A$. hypogaea, two autotetraploids, and two synthetic hybrids and concluded that there was significant variation within the section, limited variation 
TABLE 1. Arachis accessions screened for polymorphic seed proteins

\begin{tabular}{|c|c|c|}
\hline $\begin{array}{l}\text { Species } \\
\text { (genome type) }\end{array}$ & $\begin{array}{l}\text { Accession } \\
\text { No. }\end{array}$ & Collector* \\
\hline \multicolumn{3}{|c|}{ Section Arachis } \\
\hline \multirow[t]{2}{*}{ A. batizocoi Krap. et Greg. (B) } & 9484 & $\mathrm{~K}$ \\
\hline & 30080 & GKBSPSc \\
\hline & 30081 & GKBSPSc \\
\hline \multirow[t]{6}{*}{ A. cardenasii $(\mathrm{A})^{\dagger}$} & 36019 & $\mathrm{KSSc}$ \\
\hline & 36020 & $\mathrm{KSSc}$ \\
\hline & 36033 & $\mathrm{KSSc}$ \\
\hline & $36034-Y$ & $\mathrm{KSSc}$ \\
\hline & 36034-YF & $\mathrm{KSSc}$ \\
\hline & 36034-YO & KSSc \\
\hline A. chacoense (A) & 10602 & GKP \\
\hline \multirow[t]{7}{*}{ A. duranensis $(\mathrm{A})$} & 7988 & $\mathrm{~K}$ \\
\hline & 30061 & GKBSPSc \\
\hline & 30065 & GKBSPSc \\
\hline & 30067 & GKBSPSc \\
\hline & 30069 & GKBSPSc \\
\hline & 30070 & GKBSPSc \\
\hline & 30074 & GKBSPSc \\
\hline \multirow[t]{3}{*}{ A. glandulifera Stalker (D) } & 30091 & GKSSc \\
\hline & 30099 & GKSSc \\
\hline & 30100 & GKSSc \\
\hline A. helodes Martius ex Krap, et Greg. (A) & 30036 & GK \\
\hline \multirow[t]{2}{*}{ A. kempfmercadoi $(\mathrm{A})$} & 30085 & GKBSPScZ \\
\hline & 35001 & GKSPScGB \\
\hline A. khulaminii (A) & 30035 & $\mathrm{GK}$ \\
\hline A. magna (A) & 30097 & GKSSc \\
\hline \multirow[t]{2}{*}{ A. monticola Krap. et Rig. (AB) } & 30062 & GKBSPSc \\
\hline & 30063 & GKBSPSc \\
\hline A. otavoi (A). & 30008 & GK \\
\hline A. spegazzinii (A) & 10038 & GKP \\
\hline \multirow[t]{2}{*}{ A. stenosperma (A) } & 408 & HLK \\
\hline & 410 & HLK \\
\hline A. valida $(\mathrm{A})$ & 30011 & $\mathrm{GK}$ \\
\hline \multicolumn{3}{|c|}{ Section Erectoides } \\
\hline \multirow[t]{4}{*}{ A. appresipilla (E) } & 9990 & GKP \\
\hline & 9993 & GKP. \\
\hline & 10002 & GKP \\
\hline & 30003 & GK \\
\hline A. chiquitana $(\mathrm{E})$ & 36025 & $\mathrm{KSSc}$ \\
\hline \multirow[t]{2}{*}{ A. paraguariensis Chod. et Hassl. (E) } & $565-66$ & HLKHe \\
\hline & 30109 & GKPSe \\
\hline A. rigonii Krap. et Greg. $(\mathrm{E})$ & 114 & Unknown \\
\hline A. stenophylla $(\mathrm{E})$ & 31026 & GKPSc \\
\hline Section Extra & sae & \\
\hline \multirow{2}{*}{\multicolumn{2}{|c|}{$\begin{array}{c}\text { A. villosilicarpa Hoehne (EX) } \\
\text { Section Triseminalae }\end{array}$}} & Unknown \\
\hline & & \\
\hline A. pusilla (Benth.) (T) & 12922 & GK \\
\hline
\end{tabular}

among cultivars, and that genomic divisions within section Arachis were justified. Bianchi-Hall et al. (1993) studied seed protein polymorphism among 55 accessions of diploid section Arachis species and detected variation within and between species. The present study extends the work of these authors to include a total of 72 accessions, representing 22 species and six genome types from four sections of the genus, Arachis, Erectoides, Extranervosae, and Triseminalae; the cultivated groundnut was represented by 28 accessions, which include both subspecies. Attention was vocused on variation between sections, genome types, species, and where possible, between accessions within species. The relatedness of diploid section Arachis wild species to the cultivated groundnut is also discussed.

\section{Materials and methods}

The groundnut accessions 'used in this study' are listed in Tables 1 and 2 . All seeds were supplied by the International Crops Research Institute for the Semi-Arid Tropics (ICRISAT), Patancheru, Andhra Pradesh, India, except those of the three accessions of $A$. glandulifera, which were a gift from Prof H.T. Stalker, North Carolina State University, N.C., U.S.A. Wild 
TABLE 2. Arachis hypogaea accessions screened for polymorphic seed proteins

\begin{tabular}{|c|c|c|c|}
\hline & Identity & Synonyms & Origin \\
\hline \multicolumn{4}{|c|}{ A. hypogaea ssp. hypogaea var. hypogaea (AB) } \\
\hline \multicolumn{4}{|c|}{ Virginia type } \\
\hline \multicolumn{4}{|l|}{ Bunch subtype } \\
\hline ICG $8265^{\circ}$ & P 2416 & $\begin{array}{l}59-127 \\
\text { N.C.Acc } 17194\end{array}$ & Senegal \\
\hline ICG12158 & Chunseong & 300357 & Korea \\
\hline ICG 8859 & Tamale & $\begin{array}{l}\text { PI } 268947 \\
\text { NCAC } 16608\end{array}$ & Ghana \\
\hline ICG 11148 & Makulu Red & PI 371965 & Uganda \\
\hline ICG 2985 & $\mathrm{AH} 6712$ & A $6 / 36$ & Myanmar \\
\hline ICG 2384 & $\begin{array}{l}\text { DHT } 192 \\
\text { OV. Chiqitano }\end{array}$ & $\begin{array}{l}\text { PI } 313949 \\
\text { N.C.Acc } 17139\end{array}$ & Bolivia \\
\hline ICG 2252 & $\begin{array}{l}\text { Feng Lee Tai Kung Don } \\
\text { Gujarat Narrow Leaf }\end{array}$ & $\begin{array}{l}\text { PI } 269710 \\
\text { N.C.Acc } 38\end{array}$ & Japan \\
\hline ICG 2741 & & & India \\
\hline \multicolumn{4}{|l|}{ Runner subtype } \\
\hline ICG 2837 & Spanish Peanut & & Argentina \\
\hline ICG 7028 & VRR 171 & & India \\
\hline ICG 2621 & KANO $38 \quad \because$ & $\begin{array}{l}\text { EC } 1541 \\
\text { AH } 6637\end{array}$ & Nigeria \\
\hline ICG 2645 & Che Tse Hua Seng & EC 16668 & China \\
\hline ICG 2706 & Asiriya Mwitunde & EC 25188 & Tanzania \\
\hline ICG 4416 & Venezuela & & Venezuela \\
\hline \multicolumn{4}{|c|}{ A. hypogaea ssp. fastigiata var. fastigiata (AB) } \\
\hline \multicolumn{4}{|c|}{ Valencia type } \\
\hline ICG 10522 & Uganda Erect & PI 268551 & Uganda \\
\hline ICG 10566 & 5101 & PI 313200 & Congo \\
\hline ICG 8360 & Lonyun 6104 & NCAC 18121 & Thailand \\
\hline ICG 6230 & RCM 597-1 & $\begin{array}{l}\text { PI } 262092 \\
\text { NCAC } 16141\end{array}$ & Bolivia \\
\hline ICG 1267 & AH 7229 & & Malaysia \\
\hline ICG 1924 & RCM 593 & PI 262087 & Brazil \\
\hline \multicolumn{4}{|c|}{ A. hypagaea ssp. fastigiata var. vulgaris (AB) } \\
\hline ICG 2192 & AH 7173 & $\begin{array}{l}\text { EC } 4580 \\
\text { CPI } 12156\end{array}$ & Brazil \\
\hline ICG 365 & Mani Blanca 61 & $\begin{array}{l}\text { SH } 61 \\
\text { PI } 161867\end{array}$ & Argentina \\
\hline ICG 2233 & Philippine Pink & & Philippines \\
\hline ICG 10351 & Makanga Spanish 1 & & Malawi \\
\hline ICG 3200 & Kou Pi Hua Seng & EC 16669 & China \\
\hline ICG 10194 & $55-19$ & & Senegal \\
\hline ICG 3196 & Kalamadi & $\mathrm{EC} 4082$ & Kenya \\
\hline
\end{tabular}

Note: "PI" numbers are cited by the source of germplasm. N.C.Acc., North Carolina State University accession number; ICG, ICRISAT groundnut germplasm number.

species were selected to give emphasis to section Arachis, as most of these can be crossed with $A$. hypogaea, and the cultivars were selected to represent diverse origins, and to include members of the subspecies and botanical varieties available. Individual seeds were manually ground between two layers of Watman No. 1 filter paper with a carpenter's hammer. Material from several seeds were pooled and aliquots of ground seed $(8 \mathrm{mg})$ were extracted for $1 \mathrm{~h}$ at room temperature in $200 \mu \mathrm{L}$ of the following extraction buffer: Tris- $\mathrm{HCl}(\mathrm{pH} 6.8), 65 \mathrm{mM}$; sodium dodecyl sulphate, $2 \% \mathrm{w} / \mathrm{v}$; Pyronin G (BDH), $0.01 \% \mathrm{w} / \mathrm{v}$; glycerol, $11 \% \mathrm{w} / \mathrm{v} ;$ mercaptoethanol, $5 \% \mathrm{w} / \mathrm{v}$. Samples were then boiled for $3 \mathrm{~min}$ after which they were centrifuged briefly to remove particulate matter. Aliquots $20-40 \mu \mathrm{L}$ were electrophoresed through $10 \%$ SDS-polyacrylamide gels at $20 \mathrm{~mA}$ for 6-8 h (Laemmli 1970). Both neat and diluted samples of each accession were used, depending on whether faint or strong bands were being scored. Protein bands were visualized by staining the gels in $95 \%$ ethanol, $0.4 \% \mathrm{w} / \mathrm{v}$ Coomassie Blue R (Sigma). All accessions were scored plus $(+)$ or minus $(-)$ for each polymorphic protein band. The results were analysed statistically by cluster analysis and by Nei's coefficient of similarity (Nei and Lei 1979).

\section{Results}

Screening of. Arachis germplasm for seed protein polymorphism revealed 24 polymorphic bands ranging in size from 17600 to $49500 \mathrm{Da}$, which were numbered 1-24 in order of decreasing size (Table 3 ). Figure 1 gives the scores of all accessions represented graphically in band map form (Powell et al. 1991). All Arachis species showed unique profiles with the exception of $A$. cardenasii and $A$. duranensis. No intraspecific variation was detected among the seven $A$. duranensis accessions tested. Four accessions of $A$. cardenasii were screened, one of which, 36034 , had been separated into three lines (36034-Y, 36034-YF, and 36034-YO), where Y, YF, and YO refer to flower colour. Profiles of 36034-YO and 36034-Y were identical to each other but also to $A$. duranensis, while $36034-\mathrm{YF}$ showed a 
TABLE 3. The molecular sizes of the 24 polymorphic seed proteins that were detected in Arachis germplasm

\begin{tabular}{cc}
\hline \hline & $\begin{array}{c}\text { Approximate molecular mass } \\
\text { Protein band }\end{array}$ \\
\hline 1 & 49500 \\
2 & 48400 \\
3 & 38000 \\
4 & 37200 \\
5 & 32400 \\
6 & 31600 \\
7 & 30200 \\
8 & 29500 \\
9 & 29300 \\
10 & 28800 \\
11 & 28200 \\
12 & 27500 \\
13 & 26900 \\
14 & 26300 \\
15 & 26000 \\
16 & 22900 \\
17 & 21600 \\
18 & 21100 \\
19 & 20800 \\
20 & 20200 \\
21 & 19600 \\
22 & 19300 \\
23 & 18600 \\
24 & 17600 \\
\hline
\end{tabular}

unique profile, as did the other three accessions of $A$. cardenasii $(36019,36020$, and 36033) (Fig. 1). Figure $2 a$ shows some of the variation found in $A$. cardenasii germplasm; in total, six polymorphic proteins were detected. Collection sites of 36019 and 36020 were within about $10 \mathrm{~km}$ of each other, as were 36033 and 36034 , but these two areas were about $120 \mathrm{~km}$ apart. There is therefore variation over a fairly short distance at each location.

Three accessions of A. batizocoi were screened. Although 30080 and 30081 were collected close together $(7 \mathrm{~km})$, these two collections differ by an additional protein band (No. 8) in 30081 (Fig. 2b). Accession 30080 was identical to 9484 collected $56 \mathrm{~km}$ away. Stalker et al. (1991): in a morphological and karyotypic study of five accessions of A. batizocoi, including 9484 and 30081, found differences between them and presented evidence that chromosomal translocations may have been responsible for these differences. They could distinguish between all accessions, including 30080 (cited as 30097 in their papers; H.T. Stalker, personal communication) and 30082 , collected within $2 \mathrm{~km}$ of each other.

Only one accession of $A$. chacoense, 10602, was available for study. Variation between seeds was detected, whereby some seeds possessed an additional protein band (band No. 7; Fig. 2c). A total of 16 individual seeds were tested of which half scored positive for band No. 7 and half scored negative. We therefore refer to the absence of this extra band as 10602/A and its presence as 10602/B.

Twenty-eight accessions of the cultivated groundnut A. hypogaea L. were screened for polymorphism. These accessions represented ssp. hypogaea var. hypogaea, ssp. fastigiata var. fastigiata, and ssp. fastigiata var. vulgaris. Two polymorphic proteins were detected, band No. 7, which was present in ssp. hypogaea only and band No. 6, which was present in ssp. fastigiata only (both var. fastigiata and var. vulgaris). One exception to this was observed: accession 10351, which is A. hypogaea ssp. fastigiata, had a profile identical to A. hypogaea ssp. hypogaea (Fig. 3). Arachis monticola, the wild progenitor of $A$. hypogaea, which was represented by two accessions, was shown to possess both protein band Nos. 6 and 7, in addition to all other markers found in A. hypogaea germplasm (Fig. 3). Seed proteins did not distinguish two market types, Runner and Bunch, of A. hypogaea. ssp. hypogaea var. hypogaea (Fig. 3). Arachis hypogaea ssp. hypogaea var. hirsuta was not available for study.

The band map generated from protein data orders genotypes such that those with similar profiles are more likely to be placed close to each other than those with dissimilar profiles (Powell et al. 1991). The band map highlights the similarities and differences among accessions for protein variation (Fig. 1). It is immediately obvious that the five accessions of $A$. appresipilla, collected very close to each other, are identical to each other, whereas the six examples of $A$. cardenasii are nonidentical and are dispersed in the band map. The number of protein bands present in each accession ranged from 5 in A. pusilla to 15 in the two accessions of A. monticola. Protein bands placed to the right of the band map occur at lower frequencies than those placed to the left; this facilitates the identification of those that are unique or rare. Protein band Nos. 11 and 21 were uniquely present in $A$. khulamini $i$ and $A$. pusilla, respectively, whereas band-Nos. 10 and 23 were uniquely absent from $A$. pusilla. Marker 8 , while present in four accessions, was detected in only two species, A. batizocoi Krap. et Greg. and A. villosulicarpa Hoehne.

A similarity matrix and a minimum spanning tree derived from seed protein data are shown in Table 4 and Fig. 4, respectively. Interspecific similarities ranged from $0 \%$ (A. pusilla/A. paraguariensis and A. pusilla/A. stenophylla) to $92 \%$ (A. chacoense/A. stenosperma). A similarity of $92 \%$ represents a difference of one protein band only, in this case band No. 17. Although this protein band distinguishes $A$. chacoense from $A$. stenosperma, it was present in 38 accessions in total (Fig. 1). Among the accessions of $A$. cardenasii, the similarity varied from $91 \%(36019 / 36020)$ to $64 \%$ (36033/36034-YS), whereas similarity among the A genome species of section Arachis as a whole varied from $92 \%$ (A. chacoense/A. stenosperma) to $49 \%$ (A. chacoense/A. khulaminii; Table 4). The $A$. cardenasii accessions form a cohesive group on the minimum spanning tree (Fig. 4) with the exception of 36034-YF, and it should be noted that 36034-Y and 36034-YO (which have an identical profile to and occupy the same position on the minimum spanning tree as $A$. duranensis) are grouped with the other $A$. cardenasii accessions. It should also be noted that $A$. cardenasii 36033 is as similar to A. duranensis as it is to A. cardenasii 36030 (83.3\%; Fig. 4). The extent of variation found in A. cardenasii germplasm, both between collection sites and at one site (36034) may indicate that this species is an outbreeder.

Arachis batizocoi and A. glandulifera Stalker, while classified in section Arachis, possess genome types B and D, respectively, which are different from all other diploid section Arachis species (Smartt et al. 1978a; Stalker 1991; Stalker et al. 1991). This is reflected in their seed protein profiles (Fig. 4 and Table 4). The most similar section Arachis species to A. batizocoi is A. octavoi, which has only $44 \%$ 
Number of accessions which scored posttive for a particular bant $\begin{array}{llllllllllllllllllllllll}72 & 72 & 71 & 67 & 67 & 65 & 65 & 53 & 49 & 47 & 44 & 39 & 38 & 38 & 29 & 25 & 17 & 8 & 7 & 7 & 7 & 4 & 1 & 1\end{array}$

\begin{tabular}{|c|c|}
\hline A. apxessip110 & 9990 \\
\hline$n$ & 9993 \\
\hline 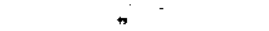 & 30003 \\
\hline$n$ & 30009 \\
\hline$n$ & 10002 \\
\hline A. cardenasif & 36019 \\
\hline$\pi$ & 36020 \\
\hline 1. chiquitara & 36025 \\
\hline A. helodes & 30036 \\
\hline A. keppfnexcado 1 & 35001 \\
\hline$n$ & 30085 \\
\hline A. candenasi & 36033 \\
\hline 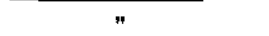 & $36034-Y$ \\
\hline$n$ & $36034-Y O-1$ \\
\hline A. duranensis & 7988 \\
\hline$\pi$ & 30065 \\
\hline n & 30067 \\
\hline$n$ & 30069 \\
\hline$n$ & 30070 \\
\hline$n$ & 30074 \\
\hline$n$ & 30061 \\
\hline A. spegazzinnil & 10038 \\
\hline A. valida & 30011 \\
\hline A. Cardenasil & $36034-Y F-3$ \\
\hline A. khulamini1 & 30035 \\
\hline A. Chacoense & $10602 / A$ \\
\hline$n$ & $10602 / B$ \\
\hline 1. stenosperma & 408 \\
\hline$n$ & 410 \\
\hline A. octavo & $\begin{array}{l}30008 \\
114\end{array}$ \\
\hline A. monticola & 30062 \\
\hline$n$ & 30063 \\
\hline A. hyp. fst vul & 10351 \\
\hline A. hyp. hyp. hyp. & 2252 \\
\hline$n$ & 2384 \\
\hline " & 2742 \\
\hline$n$ & 2985 \\
\hline$n$ & 8265 \\
\hline$n$ & 8859 \\
\hline$\pi$ & 11148 \\
\hline$n$ & 22258 \\
\hline$n$ & 2621 \\
\hline$n$ & 2645 \\
\hline$\pi$ & 2706 . \\
\hline$n$ & 2837 \\
\hline n & 4416 \\
\hline$n$ & 7028 \\
\hline A. hyp. fst. fEt & 1267 \\
\hline$n$ & 2924 \\
\hline n & 6230 \\
\hline$n$ & 8360 \\
\hline$n$ & 10522 \\
\hline " & 10566 \\
\hline A. hyo. fst yul. & 365 \\
\hline$n$ & 2192 \\
\hline$n$ & 2233 \\
\hline$n$ & -3196 \\
\hline$n$ & 3200 \\
\hline " & 10194 \\
\hline$n$ & TMV2 \\
\hline A. magna & 30097 \\
\hline A. Daxaguariensis & 30109 \\
\hline$n$ & 565 \\
\hline A. stenophy 130 & 30126 \\
\hline A. bat120001 & $\begin{array}{l}9484 \\
30080\end{array}$ \\
\hline$n$ & 30081 \\
\hline A. $\mathrm{v} 1120 \mathrm{osul1}$ carpa & 8147 \\
\hline 1. Glanduliferea & 30091 \\
\hline$n$ & 30099 \\
\hline$n$ & 30100 \\
\hline A. PUES11a & 12922 \\
\hline
\end{tabular}

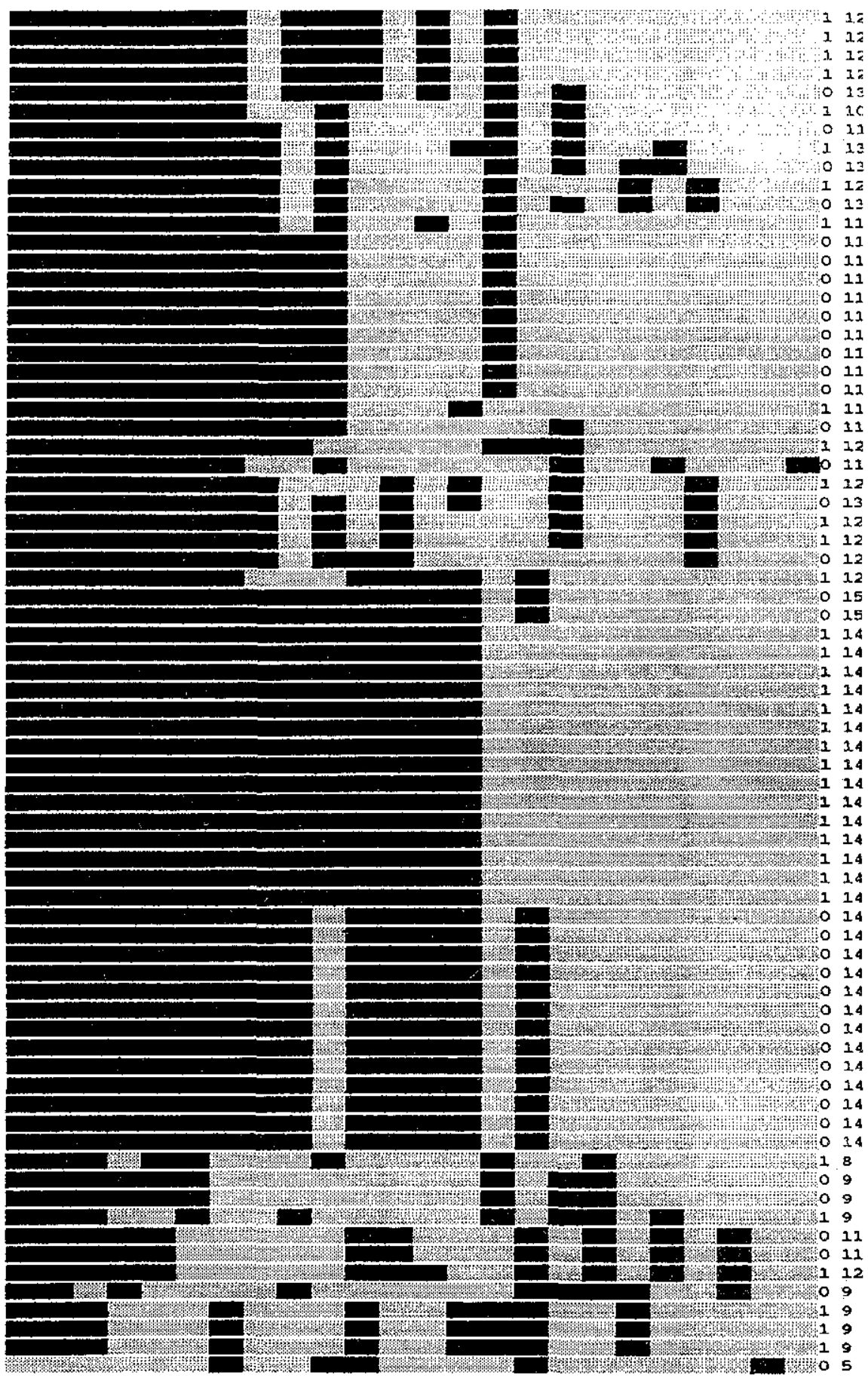

$\begin{array}{llllllllllllllllllllllll}23 & 10 & 24 & 9 & 22 & 5 & 1 & 12 & 20 & 7 & 15 & 13 & 3 & 17 & 14 & 6 & 4 & 26 & 18 & 39 & 8 & 21 & 11\end{array}$

band number

FIG. 1. Band map of polymorphic seed proteins detected in Arachis germplasm. $\mathbf{m}$, protein band present; $\square$, protein band absent. The row of numbers along the bottom of the band map identifies each band by its number. The row of numbers along the top and bottom of the band map gives the number of accessions that scored positively for each band, e.g., band No. 23 (bottom) was present in 72 (top) of the accessions tested. The column of zeros and ones that occur at the right-hand side of the band map are indicators of change; if two adjacent accessions have the same value, whether one or zero, they have identical seed protein profiles. The column of markers on the extreme right of the band map indicates the number of markers present in each accession, e.g., $A$. appresipilla 9990 scored positive for 12 markers. Note that both types of $A$. chacoense 10602 are represented (see text for further details). 
(a)

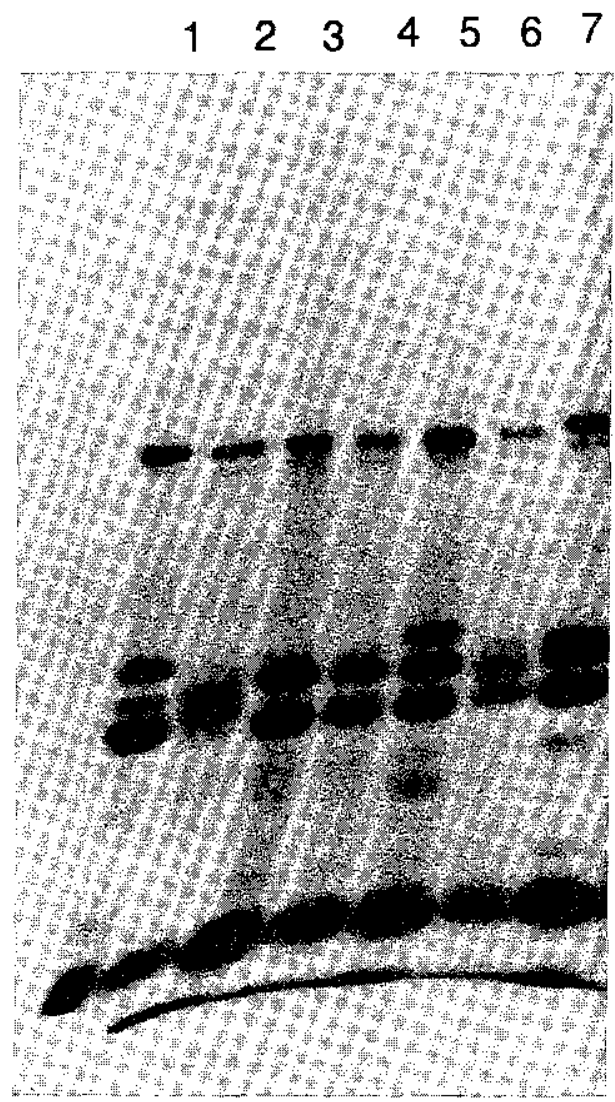

(b)

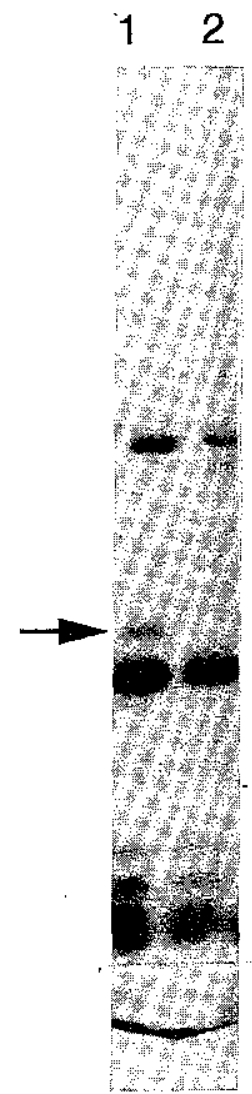

(c)

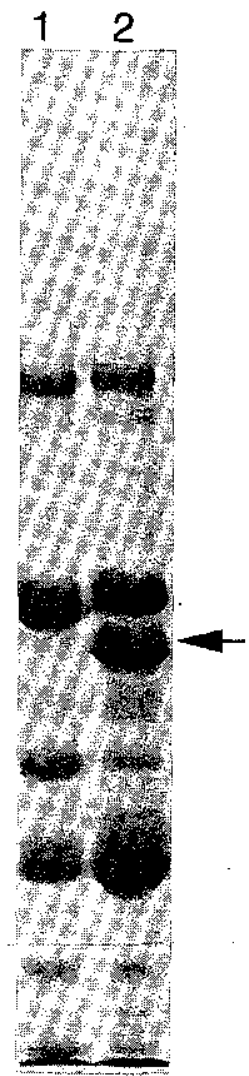

FIG. 2. Intraspecific polymorphism detected in seed proteins of wild Arachis germplasm. (a) Lane 1, A. appresipilla 9990; lane 2, A. cardenasii 36034-YF; lane 3, A. cardenasii 36034-YO; lane 4, A. cardenasii 36034-Y; lane 5, A. cardenasii 36033-Y; lane 6, A. cardenasii 36020; lane 7, A. cardenasii 36019. (b) Lane 1, A. batizocoi 30081; lane 2, A. batizocoi 9484; arrow, band No. 3 . (c) Lane 1, A. chacoense 10602 type A; lane 2, A. chacoense 10602 type B; arrow, band No. 7 .

similarity to A. batizocoi 30081 ; A. batizoco $i$ has more in common with the section Erectoides species A. rigonii Krap. et Greg., which has $60 \%$ similarity with $A$. batizocoi 9484 and $53 \%$ with $30080 / 81$. Interspecific crosses between A. batizocoi and A genome species of section Arachis have very low fertility levels (Smartt et al. 1978b). Arachis glandulifera has its greatest similarity in section Arachis with A. kempfmercadoi, or A. cardenasii 36034-YF (both 40\%), while it has $50 \%$ similarity with $A$. rigonii and $40 \%$ with A. appresipilla, both in section Erectoides. Arachis glandulifera is distinguished from other section Arachis species on morphological and karyotypic grounds. In addition, A. glandulifera does not cross-hybridize with $A$. hypogaea, and hybrids between $A$. glandulifera and either $A$. duranensis (A genome) or A. batizocoi (B genome) are sterile (Stalker 1991). Arachis batizocoi (30080) and Arachis glandulifera were distinct from each other, having only $33 \%$ similarity. Arachis glandulifera has $41 \%$ similarity with A. hypogaeal A. monticola, as close to those as to any other species in section Arachis.

Arachis monticola possesses the A and B genomes similar to A. hypogaea and is generally considered to be a wild type of the cultivated groundnut. In this study, the seed protein profile of $A$. monticola was identical to a combination of markers found in the two subspecies of $A$. hypogaea and from these results it would not be unreasonable to propose that $A$. monticola gave rise to both $A$. hypogaea ssp. nypogaea and A. hypogaea ssp. fastigiata (Fig. 3). Conversely, A. monticola may have arisen by hybridization of the two subspecies. Arachis hypogaea is represented in Fig. 4 and Table 4 by $A$. monticola (i.e., it occupies the same position).

Much speculation on the identity of the diploid precursors of A. monticola/A. hypogaea exists in the literature (Smartt et al. 1978a; Klozova et al. 1983; Stalker and Moss 1987; Krishna and Mitra 1988; Kochert et al. 1991; Singh et al. 1991; Halward et al. 1992; Paik-Ro et al. 1992; BianchiHall et al. 1993). The results presented here indicate that A. spegazzinii ( $73 \%$ similarity with $A$. monticola) or A. octavoi $(69 \%$ similarity with $A$. monticola) may be candidates for the A genome donor, while A. batizocoi, which is the only $B$ genome diploid species identified to date, shares $50 \%$ similarity with $A$. monticola. Given that the seed protein profiles reported here distinguish the $A$ and $B$ genomes (see discussion above on $A$. batizocoi) these percentage similarities lend weight to the argument that A. batizocoi (B genome) and A. spegazzinii (A genome) or A. octavoi (A genome) may be considered as possible genome donors to the cultivated groundnut. On examining the profiles in more detail (Fig. 5), it becomes apparent that all bands present in A. monticola are to be found in either A. batizoco $i$ (30081) or A. spegazzinii, whereas if $A$. batizocoi is combined 
with $A$. octavoi one band (No, 20) is present in A. monticola but absent from the combination. Three-bands (Nos, $-2,-8$, and 18) are present in A. batizocoi but absent from A. monticola.

The five section Erectoides species that were included in this study represented two series, Tetrafoliolatae and Procumbense. The most similar, 64\%, were A. paraguariensis and A. stenophylla, both Tetrafoliolatae (Table 4). Similarities in Procumbensae species range from 47 to $60 \%$ and 24 to $57 \%$ for similarities between Tetrafoliolatae and Procumbensae species. Although this is in line with the taxonomic series affiliations, with the exception of $A$. stenophylla, each species exhibited greater similarity with nonErectoides species, e.g., A. chiquitana/A. helodes, $86 \%$. This is reflected in the dispersion of the Erectoides species throughout the minimum spanning tree with each of the three main groupings including at least one Erectoides species (Fig. 4).

Arachis villosulicarpa and A. pusilla were the sole representatives of sections Extranervosae and Triseminalae, respectively, available for this study. These species were distinguished from each other ( $8 \%$ similarity) and from:all other species (Table 4). The B genome species $A$. batizoco was the most similar to $A$. villosulicarpa (43\%), while the $D$ genome species $A$. glandulifera was the closest to A. pusilla (27\%).

The B, D, Ex, and T genome species are grouped together in the minimum spanning tree, although the degree of similarity between the genome types is not particularly high (see Fig. 4).

\section{Discussion}

It has been estimated that; on morphological, karyotypic, and cross fertility criteria, the genus Arachis consists of 15-25 species with precise assignations of all accessions being incomplete (Stalker and Moss 1987; Stalker 1990), though up to 77 species have been suggested (IBPGR 1990). Estimates of the extent of variation within a genus or within a given species can be instrumental in clarifying such situations. In addition, a knowledge of the relatedness between species can assist in designing programs for gene mapping and for the introgression of novel characters from wild species into cultivars. For these reasons a range of Arachis germplasm was screened for polymorphic seed proteins. Twenty-four polymorphic proteins were identified by screening 72 accessions representing 22 species and six genome types.

All species had individual profiles with the exception of A. cardenasii 36034 , which was identical with all the accessions of $A$. duranensis. Interspecific variation among accessions of $A$. cardenasii, A. chacoense, $A$. batizocoi, and $A$. hypogaea was also detected using this method, while it was observed that other species, e.g., A. appresipilla (five accessions), A. duranensis (seven accessions), and A. glandulifera (three accessions), showed no such variation. Klozova et al. (1983), Singh et al. (1991), and Bianchi-Hall et al. (1993) also examined seed protein variation in Arachis germplasm and identified 27,19 , and 25 polymorphisms, respectively. The disparity in the number of markers detected may reflect differences in extraction procedures or electrophoresis conditions. Singh et al. (1991) found that among six section Arachis species, $A$. chacoense and A. stenocarpa (accession HLK 410, now known and identified in this paper as $A$. stenosperma) were identical to each other, though dif-

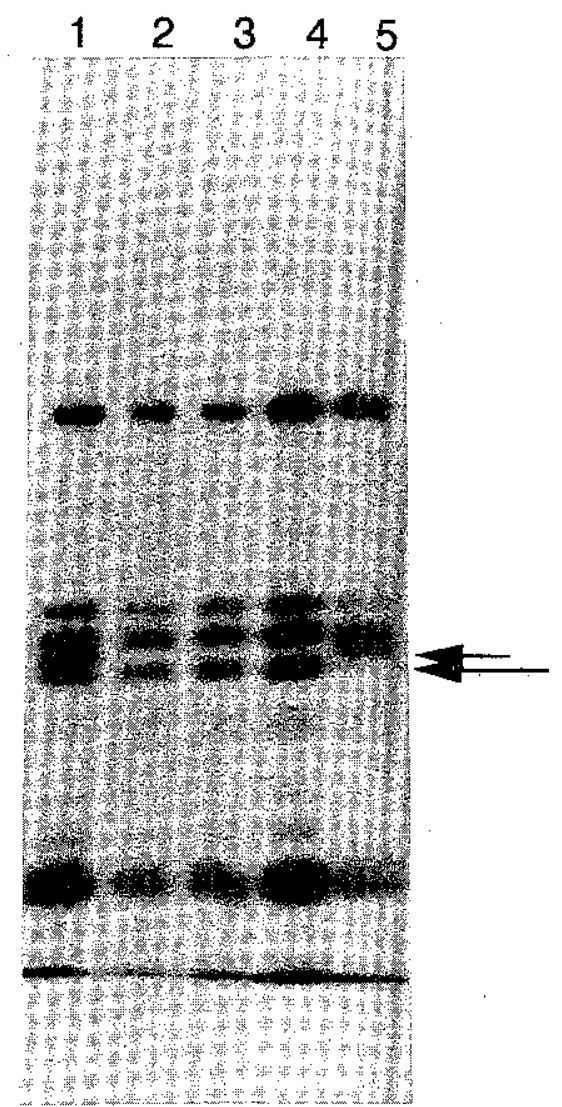

Fig. 3. Seed protein polymorphism detected in Arachis hypogaea and A. monticola germplasm; band Nos. 6 (upper) and 7 (lower) are indicated by arrows. Lane 1, A. monticola 30062; lane 2, A. hypogaea ssp. fastigiata var. vulgaris 10351; lane 3, A. hypogaea ssp. hypogaea var. hypogaea 2706; lane 4, A. hypogaea ssp. hypogaea var. hypogaea 2384; lane 5, A. hypogaea ssp. fastigiata var. fastigiata 1267.

ferences were detected in the present study. A similar outcome was found with A. cardenasii 36034-Y and 36034-. $\mathrm{YO}$, which were identical to $A$. duranensis. In the present study one protein band, No. 3 , was found to be polymorphic among accessions of $A$. batizocoi. Singh et al. (1991) also identified a single polymorphism between the $A$. batizoco $i$ accessions 9484 and 30081 , which corresponds in gel position to marker No. 3, although the estimation of size differs somewhat, 38000 for band No. 3 compared with $48000 \mathrm{Da}$ for that of Singh et al. (1991). These authors also reported that $A$. batizocoi clustered separately from the other species tested. In contrast with the present study, they observed three protein bands that distinguished the two subspecies of $A$. hypogaea. However, it is noteworthy that their protein bands of 44000 and $42000 \mathrm{Da}$ probably correspond to band Nos. 6 and 7 in the present study and that these two proteins distinguish the two subspecies of $A$. hypogaea. The third A. hypogaea polymorphism detected by Singh et al. was a protein of $45000 \mathrm{Da}$, which was present in all but one of the accessions studied. This accession was ICG 7368 , which was not available for the present study. The present study found A. monticola to be equally similar to both subspecies of $A$. hypogaea, while the third polymorphic band detected by Singh et al. (1991) resulted in A. monticola having greater similarity with subspecies hypogaea. BianchiHall et al. (1993) investigated seed protein polymorphism in 


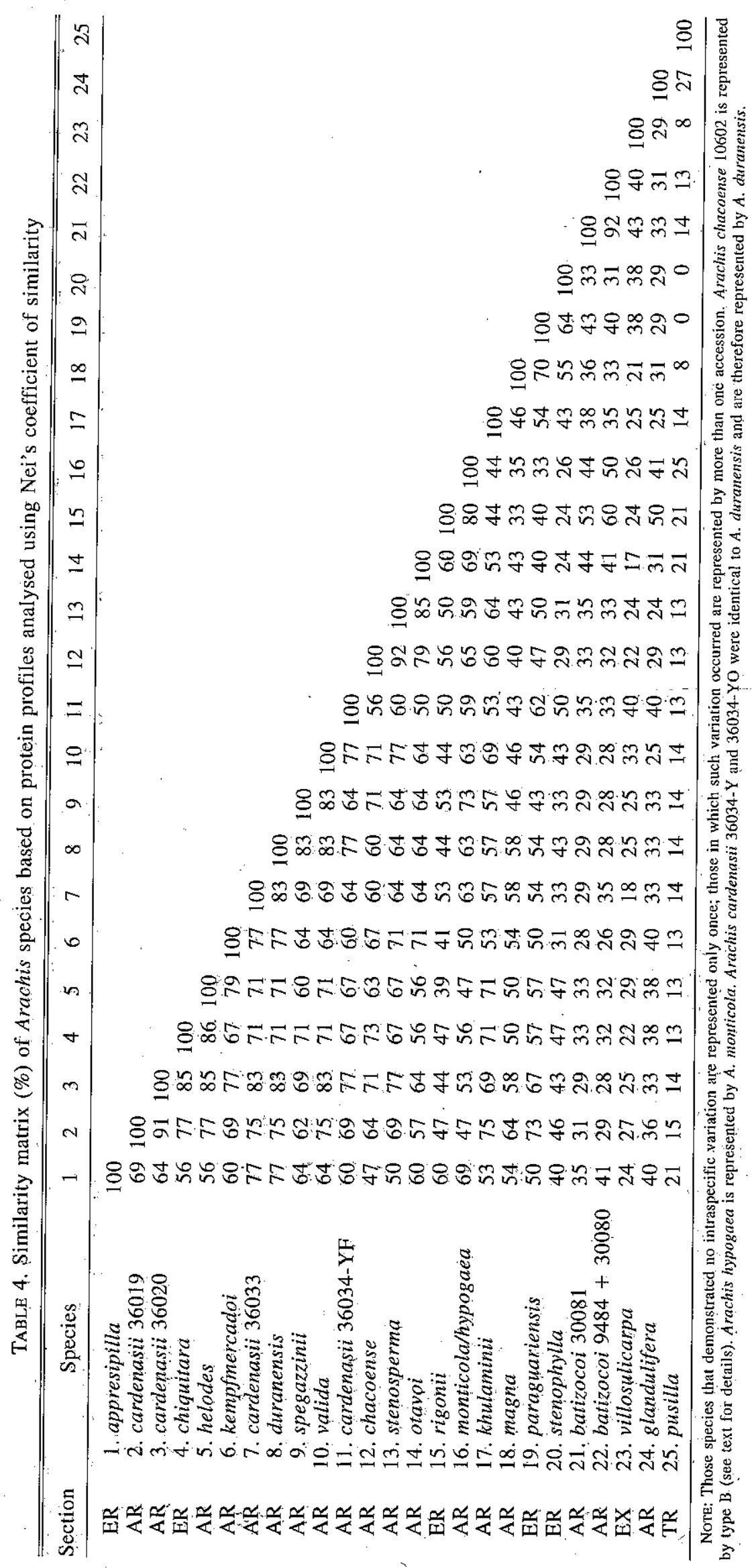




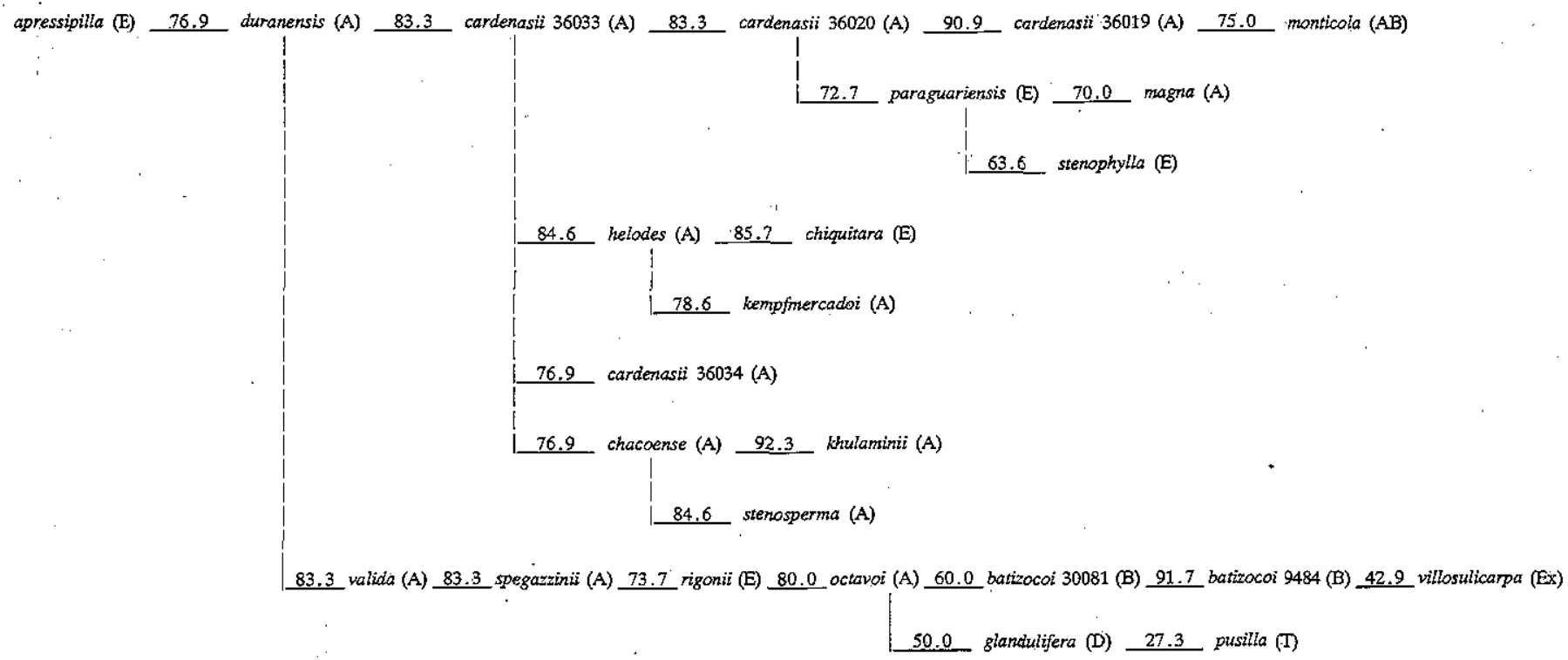

FIG. 4. Minimum spanning tree of Arachis species based on seed proteins. Species that showed no intraspecific variation are represented once only; those in which such variation occurred are represented by more than one accession. Arachis chacoense 10602 is represented by type B (see text for details). Arachis hypogaea is represented by A. monticola.
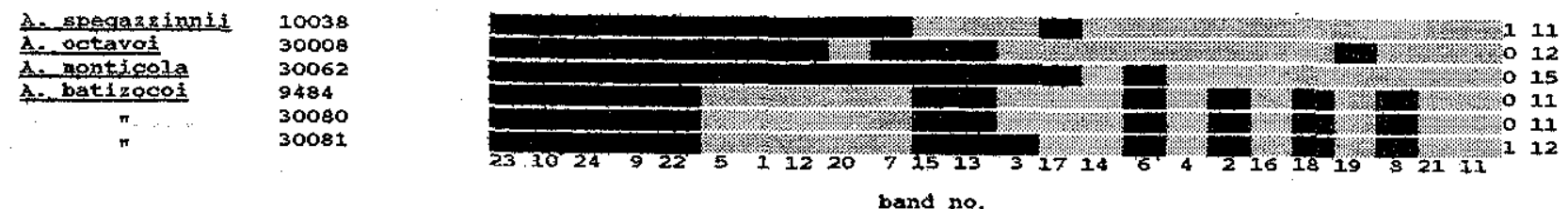

Fig. 5. Band map of selected Arachis accessions showing the relatedness of the possible donors of the A and $\mathbf{B}$ genomes, found in the cultivated peanut, to $A$. monticola.

section Arachis wild species. In agreement with the present study, they found variation in $A$. cardenasii germplasm, but in contrast, they reported differences between accessions of A. duranensis, which the present study did not detect. Variations that they reported for A. helodes and A. correntina were not investigated here because of unavailability of seed material.

The question of the possible diploid progenitor species of $A$. hypogaea/A. monticola has been addressed by various researchers using different methodologies. Arachis batizocoi, being the only $\mathrm{B}$ genome species as yet identified, is usually considered as being closely related to the $\mathrm{B}$ genome donor of the AB tetraploid species. This assumption is supported by cytogenetic data (Smartt et al. 1978a), by results obtained from seed protein studies (Klozova et al. 1983; Singh et al. 1991; the research reported here), and from a study of arachin immunoprecipitates (Krishna and Mitra 1988). However, results from restriction fragment length polymorphism (RFLP) analysis did not indicate a particularly close relatedness of $A$, batizocoi to the cultivated groundnut (Kochert et al. 1991; Paik-Ro et al. 1992). Bianchi-Hall et al. (1993) and the present study report three additional protein bands found in $A$. batizocoi but not in $A$. hypogaea. The former authors consider this as further evidence that $A$. batizoco is not a progenitor of A. hypogaea. The present study and that of Singh et al. (1991) and Bianchi-Hall et al. (1993) show that there is variation between accessions, so it is possible that the ancestral accessions that would give a perfect match with $A$. monticola/A. hypogaea no longer exist or have not been collected to date. Several diploid species have been proposed as the possible donor of the A genome to the A. hypogaea/A. monticola, including A. cardenasii (Smartt et al. 1978a; Klozova et al. 1983; Krishna and Mitra 1988), A. duranensis (Krishna and Mitra 1988; Singh et al. 1991; Kochert et al. 1991; Paik-Ro et al. 1992), A. ipaensis (Kochert et al. 1991), and A. spegazzinii (Kochert et al. 1991; the present study). As yet, no diploid species consistently having sufficient similarity to the cultivated groundnut to be considered as the definitive donors of the $\mathrm{A}$ and $\mathrm{B}$ genomes to A. hypogaea/A. monticola have been identified. The variation identified in $A$. cardenasii must strengthen the case for this being an ancestral species.

Assessments of variation within the genus based on seed proteins, RFLPs or random amplified polymorphic DNAs (RAPDs) agree that while there is considerable variation within the genus as a whole, there is surprisingly little variation among cultivars of $A$. hypogaea (Singh et al. 1991; Kochert et al. 1991; Halward et al. 1992; the present study). Singh et al. (1991) detected 19 protein bands in total of which 3 were polymorphic among cultivars. In the research reported here 24 markers were identified of which only 2 were polymorphic among cultivars. It may be, as Kochert et al. (1991) suggested, that very obvious gross morphological polymorphisms are the result of a small number of subtle genotypic differences. In this report several groups among the A genome species were delineated on the minimum spanning tree (Fig. 4). However, the E genome species did not form a cohesive group. This agrees with results obtained using RAPDs whereby it was suggested that at least some section Erectoides species had greater similarity to section Arachis species than would be expected based on morphological or 
cytogenetic data (Halward et al. 1992). Species with B, D, $\mathrm{Ex}$, or $\mathrm{T}$ genomes were clearly distinguished by seed protein polymorphism.

In summary, polymorphic seed proteins were useful in estimating variation among different accessions of certain Arachis species and could distinguish between species and between genome types, although the results do not always reflect the differences between sections of the genus that have been determined based on crossability between species, morphology, and on cytogenetic data.

\section{Acknowledgements}

This work was supported by funds from the U.K. Overseas Development Administration and the Scottish Office Agriculture and Fisheries Department.

Bianchi-Hall, C.M., Keys, R.D., Stalker, H.T., and Murphy, J.P. 1993. Diversity of seed storage protein patterns in wild peanut (Arachis, Fabaceae) species. Plant Syst. Evol. 186: 1-15.

Bulinska-Radomska, Z., and Lester, R.N. 1986. Phylogeny of chromosome races of Festuca arundinacae and F. mairei (Poaceae) as indicated by seed protein electrophoresis. Plant Syst. Evol. 152: 153-166.

Bulinska-Radomska, Z., and Lester, R.N. 1988. Intergenic relationships of Lolium, Festuca and Vulpia (Poaceae) and their phylogeny. Plant Syst. Evol. 159: 217-227.

Duvall, M.R., and Biesboer, D.D. 1989. Comparisons of electrophoretic seed protein profiles among North American populations of Zizania. Biochem. Syst. Ecol. 17: 39-43.

Gregory, W.C., Krapovickas, A., and Gregory, M.P. 1980. Structures, variation, evolution and classification in Arachis. In Advances in legume science. Edited by R.J. Summerfield and A.K. Bunting. Royal Botanic Garden, Kew, pp. 469-481.

Halward, T., Stalker, T., LaRue, E., and Kochert, G. 1992. Use of single-primer DNA amplifications in genetic studies of peanut (Arachis hypogaea L.). Plant Mol. Biol. 18: 315-325.

IBP.GR 1990. International crop network series. 2. Report of a Workshop on the Genetic Resources of Wild Arachis Species. Including Preliminary Descriptors for Arachis (IBPGR/ ICRISAT). International Board for Plant Genetic Resources, Rome.

Khan, M.A. 1992. Seed-protein electrophoretic patterns in Brachypodium P. Beauv. species. Ann. Bot. (London), 70: 61-68.

Klozova, E., Turkova, V., Smartt, J., Pitterova, K., and Svachulova; J. 1983. Immunochemical characterization of seed proteins of some species of the genus Arachis L. Biol. Plant. 25: 210-208.

Kochert, G., Halward, T., Branch, W.D., and Simpson, C.E. 1991. RFLP variability in peanut (Arachis hypogaea L.) cultivars and wild species. Theor. Appl. Genet. 81: 565-570.

Krishna, T.G., and Mitra, R. 1988. The probable genome donors to Arachis hypogaea L. based on arachin seed storage protein. Euphytica, 37: 47-52.

Ladizinsky, G., and Hymowitz, T. 1979. Seed protein electrophoresis in taxonomic and evolutionary studies. Theor. Appl. Genet. 54: 145-151.
Laemmli, U.K. 1970. Cleavage of structural proteins during the assembly of the head of bacteriophage T4. Nature (London), 227: 680-685.

Moss, J.P., Singh, A.K., Sastri, D.C., and Dundas, I.S. 1988. Wide hybridization in legumes at ICRISAT. In Biotechnology in Tropical Crop Improvement: Proceedings of the International Biotechnology Workshop, 12-15 January 1987, ICRISAT Center, Patancheru, India. pp. 87-95.

Navot, N., and Zamir, D. 1987. Isozyme and seed protein phylogeny of the genus Citrullus (Cucurbitaceae). Plant Syst. Evol. 156: 61-67.

Nei, M., and Lei, W.H. 1979. Mathematical model for studying genetic variation in terms of restriction endonucleases. Proc. Natl. Acad. Sci. U.S.A. 76: 5267-5273.

Paik-Ro, O.G., Smith, R.L., and Knauft, D.A. 1992. Restriction length polymorphism evaluation of six peanut species within the Arachis section. Theor. Appl. Genet. 84: 201-208.

Panda, R.C., Kumar, O.A., and Rao, K.G.R. 1986. The use of seed protein electrophoresis in the study of phylogenetic relationships in Chili pepper (Capsicum L.). Theor. Appl. Genet. 72: $665-670$.

Powell, W., Phillips, M.S., McNicol, J.W., and Waugh, R. 1991. The use of DNA markers to estimate the extent and nature of genetic variability in Solanum tuberosum cultivars. Ann. Appl. Biol. 118: 423-432.

Ressler, P.M. 1980. A review of the nomenclature of the genus Arachis. Euphytica, 29: 813-817.

Sathaiah, V., and Reddy, T.P. 1985. Seed protein profiles of castor (Ricinus communis L.) and some Jatropha species. Genet. Agric. 39: 35-43.

Singh, A.K., Sivaramakrishnan, S., Menghesha, M.H., and Ramaiah, C.D. 1991. Phylogenetic relations in section Arachis based on seed protein profile. Theor. Appl. Genet. 82: 593-597.

Smartt, J., and Stalker, H.T. 1982. Peanut science and technology. Edited by H.E. Pattee and C.T. Young. American Peanut Research Education Society, Yoakum, Texas: pp. 21-49.

Smart, J., Gregory, W.C., and Gregory, M.P. 1978a. The genomes of Arachis hypogaea. 1. Cytogenetic studies of primitive genome donors. Euphytica, 27: 665-675.

Smartt, J., Gregory, W.C., and Gregory, M.P. 1978b. The genomes of Arachis hypogaea. 2. The implications in interspecific breeding. Euphytica, 27: 677-680.

Stalker, H.T. 1985. Proceedings of an International Workshop on Cytogenetics of Arachis. ICRISAT, Patancheru, India. pp. $65-79$.

Stalker, H.T. 1990. A morphological appraisal of wild species in section Arachis of peanuts. Peanut Sci. 17: 117-122.

Stalker, H.T. 1991. A new species in section Arachis of peanuts with a D genome. Am. J. Bot. 78: 630-637.

Stalker, H.T., and Moss, J.P. 1987. Speciation, cytogenetics and utilization of Arachis species. Adv. Agron. 41: 1-40.

Stalker, H.T., Dhesi, J.S., and Parry, D.C. 1991. An analysis of the B genome species Arachis batizocoi (Fabaceae). Plant Syst. Evol. 174: 159-169. 